\title{
Evaluation of Sensory Nerve Conduction Studies and Hematologic Parameters in Restless Legs Syndrome
}

\author{
Huzursuz Bacaklar Sendromunda Duysal Sinir İletim Çalışmaları ve Hematolojik \\ Parametrelerin Değerlendirilmesi
}

\author{
(1) Fettah Eren1, (1) Ayşegül Demir ${ }^{1}$, (1) Şerefnur Öztürk² \\ 1 University of Health Sciences Turkey, Konya Training and Research Hospital, Clinic of Neurology, Konya, Turkey \\ 2Selcuk University Faculty of Medicine, Department of Neurology, Konya, Turkey
}

\begin{abstract}
Objective: Restless legs syndrome (RLS) presents with sensory symptoms such as burning in the legs, patients want to move their legs. Symptoms become apparent at rest and at night. The aim of this study was to investigate the relationship between sensory nerve conduction and hematologic parameters in RLS.

Materials and Methods: Forty-five patients with RLS and 45 healthy controls were included in the study. Age, sex, and chronic diseases of the patients were questioned. Hemoglobin, mean corpuscular volume (MCV), mean corpuscular hemoglobin (MCH), mean corpuscular hemoglobin concentration (MCHC), and ferritin values were recorded. Ulnar, median, and sural sensory nerve amplitude, latency and conduction velocity were evaluated in a electroneuromyography laboratory. Data were analyzed using descriptive, parametric and nonparametric tests with the SPSS 21 software.

Results: There were $22(49 \%)$ female and $23(51 \%)$ male patients with RLS in the study. The mean age was $57.31 \pm 14.47$ years. Mean blood values were as follows: Hemoglobin (g/dl) 14.06 1.88 ; MCV (fl) 85.70 (55.7-96.5); MCH (pg) 28.45 (17.6-32.5), and ferritin (ng/ml) 31.30 (4-848). There was no difference in terms of blood values between RLS and control group ( $p>0.05$ ). Sural nerve conduction velocity was slower in patients with RLS ( $\mathrm{p}=0.01$ ). Sural nerve latency was longer $(\mathrm{p}=0.01)$. Other nerve conduction parameters were equal in the study and control groups $(\mathrm{p}>0.05)$

Conclusion: Central nervous system dopaminergic mechanisms, genetic transmission, and low ferritin levels are the main factors in the pathogenesis of RLS. There is less focus on the peripheral nervous system. In this study, sural nerve conduction velocity and latency were associated with RLS. However, there was no correlation between ferritin levels and nerve conduction.
\end{abstract}

Keywords: Restless legs syndrome, sensory nerve, ferritin

$\ddot{O} \mathbf{z}$

Amaç: Huzursuz bacaklar sendromu (HBS) bacaklarda yanma gibi duysal yakınmalar ile ortaya çıkan bir hastalıktır. Hastalar bacaklarını hareket ettirmek isterler. Semptomlar istirahatle ve geceleri belirginleşir. Bu çalı̧̧ma ile HBS'de duysal sinir iletimlerinin hematolojik kan parametreleri ile ilişkisinin incelenmesi amaçlanmıştır.

Gereç ve Yöntem: Çalışmaya 45 HBS'li hasta ve 45 sağlıklı kontrol dahil edildi. Hastaların yaş, cinsiyet ve kronik hastalıkları sorgulandı. Hemoglobin, ortalama korpusküler hacim (MCV), ortalama korpusküler hemoglobin $(\mathrm{MCH})$, ortalama korpusküler hemoglobin konsantrasyonu (MCHC) ve ferritin değerleri kaydedildi. Ulnar, medyan ve sural duysal sinir amplitüd, latans ve iletim hızı elektronöromiyografi laboratuvarında değerlendirildi. Veriler SPSS 21 kullanılarak tanımlayıc1, parametrik ve nonparametrik testler ile analiz edildi.

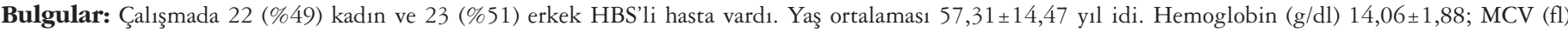
$85,70(55,7-96,5) ; \mathrm{MCH}(\mathrm{pg})$ 28,45 (17,6-32,5) ve ferritin (ng/ml) 31,30 (4-848) seviyelerindeydi. HBS ve kontrol grubu arasında kan değerleri açısından fark saptanmadı $(\mathrm{p}>0,05)$. Sural sinir iletim hızı HBS'li hastalarda daha düşüktü $(\mathrm{p}=0,01)$. Sural sinir latansı daha uzundu $(\mathrm{p}=0,01)$. Diğger sinir iletimleri hasta ve kontrol grubunda benzerdi $(\mathrm{p}>0,05)$.

Sonuç: HBS patogenezinde santral sinir sistemi dopaminerjik mekanizmaları, genetik geçiş ve düşük ferritin değerleri ön plandadır. Periferik sinir sistemi üzerinde daha az durulmaktadır. Bu çalışmada HBS hastalı̆̆ı ile sural sinir iletim hızı ve latansı arasında ilişki olduğu belirlenmiştir. Ancak ferritin seviyesi ve sinir iletimleri arasında ilişki saptanmamıştır.

Anahtar Kelimeler: Huzursuz bacaklar sendromu, duysal sinir, ferritin

Address for Correspondence/Yazışma Adresi: Fettah Eren MD, University of Health Sciences, Konya Training and Research Hospital, Clinic of Neurology, Konya, Turkey

Phone: +90 3322244007 E-posta: dreren42@hotmail.com ORCID: orcid.org/0000-0001-6834-0827

Received/Gelis Tarihi: 17.11.2019 Accepted/Kabul Tarihi: 18.08 .2020

It was presented as a controversial e-poster at the $5^{\text {th }}$ National Neurology Congress held in November 2019.

${ }^{\circ}$ Copyright 2020 by Turkish Neurological Society

Turkish Journal of Neurology published by Galenos Publishing House. 


\section{Introduction}

Restless legs syndrome (RLS) is a sensorimotor disease, in which the symptoms become more pronounced at rest, causing the desire to move the legs (1). The disease presents with different sensory symptoms such as tingling, aching, prickling, burning or like an electric shock nerve type pain in the arms and/or legs. The occurrence of symptoms typically has a circadian rhythm. Symptoms are more pronounced in the evening and at night (2). The prevalence of the disease is $6-12 \%$ and it is one of the most common neurologic diseases (3). It may be primary or secondary to hereditary or systemic diseases (4). Among the secondary causes, diabetes mellitus (DM), renal failure, iron deficiency, and pregnancy are the leading causes (5).

Polyneuropathies have an important place in the etiology of RLS $(6,7,8)$. The frequency of RLS in polyneuropathies ranges from $5.2 \%$ to $54 \%(9,10,11)$. RLS does not appear to be secondary to all polyneuropathies. The disease varies according to the polyneuropathy subtype $(12,13)$. Its frequency is higher, especially in patients with chronic inflammatory demyelinating polyneuropathy (CIDP) (14). Sensory symptoms in the disease are particularly associated with small fiber and axonal involvement (8). It is more common in various painful neuropathies due to DM, renal failure, Charcot-Marie-Tooth disease, and cryoglobulinemia (12). However, the relationship between RLS and polyneuropathy is still a matter of debate $(9,13)$.

Iron deficiency is one of the most accepted risk factors in the etiopathogenesis of RLS. Changes in iron homeostasis can lead to disease symptoms. Cerebral iron homeostasis varies according to cellular energy demand and the structure of the blood-brain barrier. Cerebrospinal fluid (CSF) ferritin is lower in patients with RLS compared with controls. Low ferritin levels in blood and CSF are associated with disease severity (15).

In this study, it was aimed to electrophysiologically evaluate the sensory nerve fibers and examine the relationship between nerve conduction, hematologic values, and blood ferritin levels in patients with RLS.

\section{Materials and Methods}

This study was conducted in patients who were admitted to the neurology outpatient clinic and followed up with a diagnosis of RLS. Local ethical approval was obtained for the study from the Selcuk University Hospital Clinical Research Ethics Committee (meeting number: 2019/15, decision number: 2019/339). No patients were investigated without informed consent, and their data were not included in the study.

Forty-five patients who were followed up with a diagnosis of RLS between March 2017 and June 2019 and 45 healthy controls were included in the study. The diagnosis of the disease was made in accordance with the questionnaire form prepared by the International RLS Study Group (16). Medical history, examination records, brain, cervical, lumbar magnetic resonance images of the patients and their treatments were analyzed retrospectively. Neurologic examinations were performed. Patients with polyneuropathy, lumbosacral radiculopathy, amyotrophic lateral sclerosis, myeloma, multiple sclerosis, Parkinson's disease, poliomyelitis, DM, amyloidosis, previous gastrectomy, cancer, endocrinologic disorders, chronic obstructive pulmonary disease, systemic inflammatory disease, hematologic disease, chronic kidney or liver failure were excluded. Patients aged 18-65 years were included in the study. Patients during pregnancy and lactation, and those receiving steroids, B12 and iron therapy were excluded from the study.

Blood samples were obtained from the antebrachial vein, put into tubes containing ethylenediaminetetraacetic acid, and evaluated with a Diagon kit in a Mindray BC-800 device for hematologic examinations. Hemoglobin ( $\mathrm{Hb})$, mean corpuscular volume $(\mathrm{MCV})$, mean corpuscular hemoglobin $(\mathrm{MCH})$, mean corpuscular hemoglobin concentration (MCHC), and ferritin values from blood samples were analyzed. The patients were divided into two groups according to the ferritin levels, <50 ng/ $\mathrm{ml}$ and $\geq 50 \mathrm{ng} / \mathrm{ml}$.

Nerve conduction studies were performed using the Neuropack Nihon Kohden Corporation Model MEB-9200K (2005, Japan) electroneuromyography device using $20 \mathrm{~Hz}-10$ $\mathrm{kHz}$ filter setting and $50 \mathrm{~ms}$ analysis time. Measurements were made antidromically with the superficial electrode recording method. The patients were rested for 15 minutes at $22-24{ }^{\circ} \mathrm{C}$ room temperature before the examination and the extremity temperature was kept above $31{ }^{\circ} \mathrm{C}$. Upper extremity nerves were stimulated from the wrist and the median nerve response was recorded from the $2^{\text {nd }}$ finger and the ulnar nerve response from the $5^{\text {th }}$ finger with a distance of $12 \mathrm{~cm}$. In the lower extremity, the right sural nerve was stimulated from the cruris and recorded with a distance of approximately $14 \mathrm{~cm}$ from the outer malleolus. Stimulation was started with 0 Volt current intensity. The current intensity was increased until the compound sensory nerve action potential (SNAP) amplitude reached the highest level. Care was taken to distinguish SNAP from motor response artifact. Distal latencies, SNAP amplitudes and conduction velocities of bilateral median and ulnar sensory nerves were measured. Distal latency, SNAP amplitude, and sensory nerve conduction velocity of the right sural nerve were evaluated. All electrophysiologic examinations were performed by the same investigator in the study and control groups.

\section{Statistical Analysis}

The Statistical Package for the Social Sciences 21.0 package software (SPSS Inc., Armonk, NY, USA) program was used for data analysis. Normality analysis was performed using the Kolmogorov-Smirnov test. Results were expressed using descriptive statistical methods such as mean \pm standard deviation or median value (minimum - maximum) according to normality analysis. The Kruskal-Wallis, Mann-Whitney U, and independent samples t-test were used for comparing the means. Spearman's correlation test was used to evaluate the relationship between data. The results were evaluated at a 95\% confidence interval, and the significance level was $\mathrm{p}<0.05$. Correlation coefficients between $0-0.25$ were considered as no correlation, $0.25-0.50$ as weakmoderate correlation, $0.50-0.75$ as strong correlation, and 0.75 1.00 as very strong correlation.

\section{Results}

There were a total of 45 patients in the study, 22 (49\%) women and $23(51 \%)$ men. Forty-five healthy controls of similar age and sex were included in the study $(\mathrm{p}>0.05)$. The mean age of the patients was $49.36 \pm 12.94$ years and the mean age of the control group was $50.39 \pm 19.50$ years $(\mathrm{p}=0.095)$. Ten $(22.2 \%)$ patients 
had hypertension, $8(17.8 \%)$ had hyperlipidemia, and $4(8.9 \%)$ had coronary artery disease. Of the patients in the control group, $8(17.8 \%)$ had hypertension, $9(20 \%)$ had hyperlipidemia, and 3 $(6.6 \%)$ had coronary artery disease.

The blood test results in patients with RLS were as follows: $\mathrm{Hb}$ $(\mathrm{g} / \mathrm{dl}) 14.06 \pm 1.88 ; \mathrm{MCV}$ (fl) 85.70 (55.7-96.5); $\mathrm{MCH}$ (pg) 28.45 (17.6-32.5); MCHC (g/dl) 33.55 (29.8-37.3), and ferritin (ng/ml) 31.30 (4-848) (Table 1).

Left upper extremity median nerve latency (ms) was $3.01 \pm 0.70$, SNAP amplitude $(\mu \mathrm{V})$ was $24.29 \pm 14.32$, and sensory nerve conduction velocity $(\mathrm{m} / \mathrm{s})$ was $49.49 \pm 8.28$. Left ulnar nerve latency $(\mathrm{ms})$ was $2.15 \pm 0.25$, SNAP amplitude $(\mu \mathrm{V})$ was $27.08 \pm 15.39$, and sensory nerve conduction velocity $(\mathrm{m} / \mathrm{s})$ was 53.59 7.90. Right upper extremity median nerve latency (ms) was $2.85 \pm 0.56$, BSAP amplitude $(\mu \mathrm{V})$ was $22.25 \pm 10.74$, and sensory nerve conduction velocity $(\mathrm{m} / \mathrm{s})$ was $50.30 \pm 10.33$. Right ulnar nerve latency (ms) was $2.14 \pm 0.28$; BSAP amplitude $(\mu \mathrm{V})$ was $24.15 \pm 12.48$ and sensory nerve conduction velocity was 53.64 4 4.36. Right lower extremity sural nerve latency (ms) was $2.73 \pm 0.51$, BSAP amplitude $(\mu \mathrm{V})$ was $13.27 \pm 6.68$, and sensory nerve conduction velocity $(\mathrm{m} / \mathrm{s}$ ) was $48.37 \pm 7.47$ (Table 2).

When the blood values were compared between the study and control groups, it was seen that both groups had similar $\mathrm{Hb}, \mathrm{MCV}, \mathrm{MCH}, \mathrm{MCHC}$, and ferritin values ( $\mathrm{p}>0.05$ ) (Table 1). Sural nerve conduction velocity was slower in patients with RLS $(p=0.01)$. Other nerve conduction values were similar in the study and control groups ( $>>0.05$ ) (Table 2). Sensory nerve conduction was compared between patients with RLS with ferritin $<50 \mathrm{ng} / \mathrm{ml}$ and ferritin $\geq 50 \mathrm{ng} / \mathrm{ml}$. Similar sensory nerve conduction velocity, latency, and SNAP amplitudes were determined in both subgroups $(\mathrm{p}>0.05)$.

When the correlation between blood values and nerve conduction values was examined, it was seen that the median sensory nerve conduction velocity slowed down with increased MCV ( $\mathrm{p}=0.01, \mathrm{r}=-0.41)$. It was observed that the

Table 1. Hemogram and ferritin values in patients with restless legs syndrome and control group

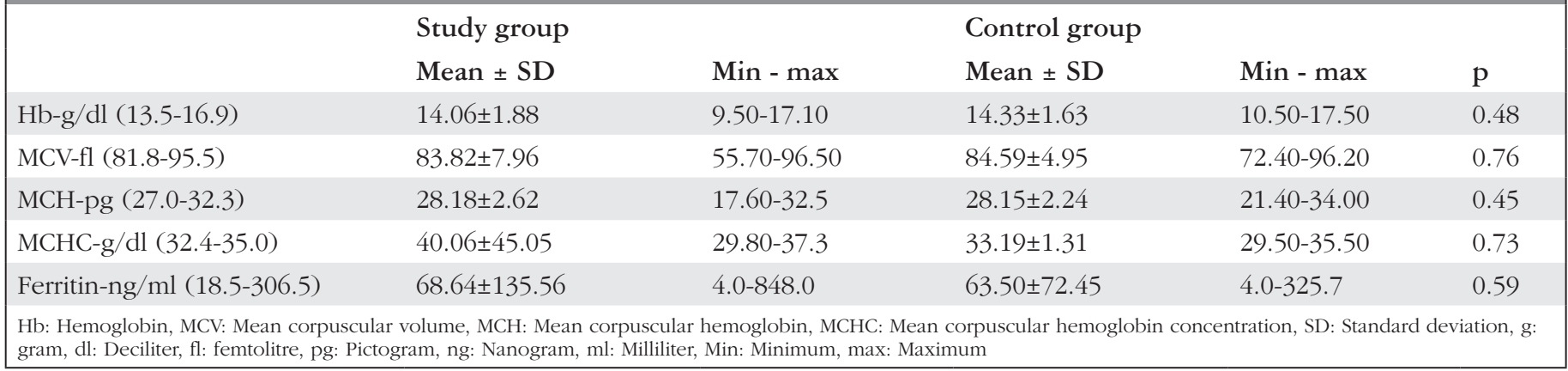

Table 2. Latency, amplitude and conduction velocity of sensory nerves in patients with restless legs syndrome and control group

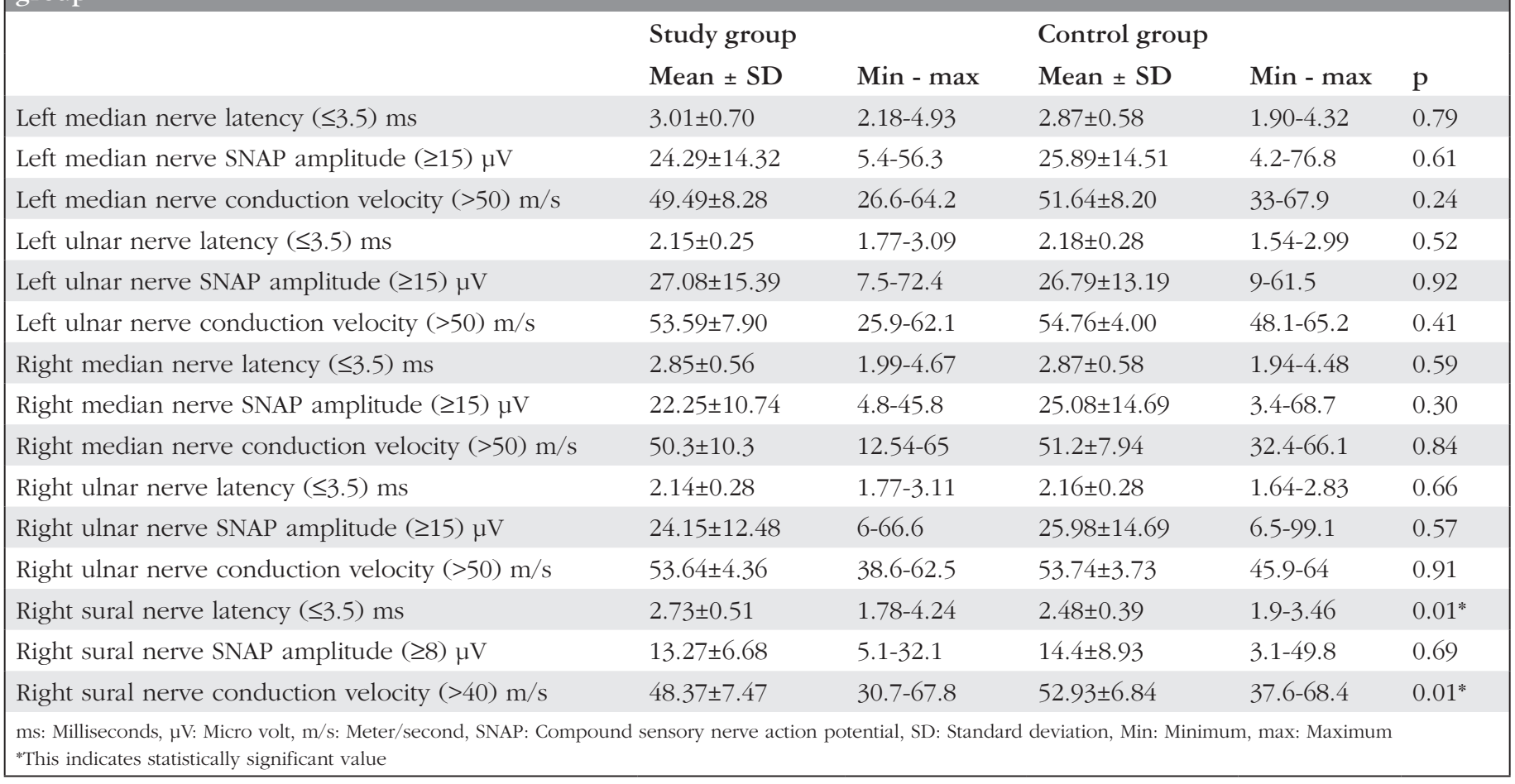


higher the ferritin level, the higher the right ulnar sensory nerve conduction velocity $(\mathrm{p}<0.01, \mathrm{r}=0.54)$. No statistically significant correlation was found between other blood tests and nerve conduction.

\section{Discussion}

The clinical presentation in patients with RLS is different sensory symptoms in the arms and/or legs such as tingling, aching, prickling, burning, and a sensation like an electric shock. It is known that the etiology of the disease is related to blood ferritin levels and iron mechanisms (2) and that as the ferritin level decreases, the severity of sensory symptoms increases. However, there are different results on the relationship between this level and sensory nerve conduction $(15,17)$. Therefore, this study was planned to evaluate blood ferritin levels and their relationship with sensory nerve conduction in patients with RLS.

When looking at studies examining the relationship between neuropathies and RLS, it is seen that there are different and conflicting results $(8,9,10,12,14)$. Different rates are also reported regarding the prevalence of polyneuropathy in RLS. When comparing 104 patients with polyneuropathy and a control group, RLS was detected in $14.9 \%$ of the controls compared with $29 \%$ of the patients (8). It was determined that the prevalence of RLS in patients with the main symptoms of pain and dysesthesia increased up to $42.2 \%$ (18). It is known that the frequency of RLS in patients with DM is higher than in the normal population. The prevalence of RLS was found as $17 \%$ in patients with type $2 \mathrm{DM}$. This significantly higher prevalence than normal is attributed to polyneuropathy with predominant sensory axonal involvement and involvement of small neuronal fibers (9). RLS was found in $35.5 \%(6 / 16)$ of patients with DM with neuropathy and $14.8 \%$ of patients with DM without neuropathy (16/104) (19). RLS has also been reported in patients with cryoglobulinemia, Charcot-Marie-Tooth disease, CIDP, and Fabry disease. The prevalence of RLS is high in hereditary painful neuropathies with small fiber involvement $(20,21,22)$. Although all these studies show different results, it is clear that neuropathy is involved in the etiology of RLS. However, studies evaluating the effects of primary RLS disease on peripheral nerves are few. In our study, all diseases associated with RLS in the literature were excluded. When our patients were compared with the control group, it was observed that the effect of RLS on sural nerve conduction was at the forefront.

The sural nerve is the largest and most distal sensory nerve of the lower extremity. It is one of the first nerves affected in the disease processes that cause polyneuropathies. Age-related changes are observed in particular. In DM-related polyneuropathy, changes in sural nervous transmission occur from the early period, sometimes before the diagnosis of the disease $(23,24)$. When patients with RLS and a control group were compared previously, it was observed that there was no statistically significant difference in terms of nerve conduction studies. However, when patients with RLS were compared within themselves in the same study, it was found that sural sensory nerve conduction velocities slowed and SNAP amplitudes decreased as the duration and severity of the disease increased (22). In our study, all patients were included in the same group, regardless of the duration and severity of symptoms. There was no impairment in sensory nerve conduction except in the sural nerve. Sural nerve involvement, on the other hand, was found to be associated with decreased sensory nerve conduction velocity.

It is known that there is a close relationship between iron deficiency and RLS; $25-45 \%$ of patients with iron deficiency anemia have RLS, and $25 \%$ of patients with RLS have iron deficiency. Iron is required during the conversion of tyrosine to L-dopa. In the next stage, L-dopa turns into dopamine. Decrease in dopamine level causes RLS symptoms to occur. Treatment with L-dopa and dopamine receptor agonists contributes to the reduction of symptoms. The most sensitive indicator of iron deficiency is the blood ferritin level (25). In particular, a blood level below $50 \mathrm{ng} / \mathrm{ml}$ is associated with an increase in the severity of RLS symptoms (26). In a previous study, it was stated that ferritin levels were low in patients with RLS compared with the control group, but the ferritin level was not associated with nerve conduction and peripheral neuropathy (22). In our study, there was no correlation between nerve conduction and ferritin levels in the study and control groups. However, it was observed that there was a negative correlation between MCV and median sensory nerve conduction velocity in our study. A positive correlation was determined between ferritin values and right ulnar sensory nerve conduction velocity in our study.

\section{Study Limitations}

The limitations of the study are as follows: In addition to median, ulnar and right sural sensory conduction studies; radial, superficial peroneal, left sural sensory conduction studies were not performed. All patients were included in the study regardless of body weight and body mass index. The number of patients was not sufficient for the evaluation of accompanying chronic diseases and patient groups with normal-abnormal nerve conduction studies.

\section{Conclusion}

Despite the high prevalence of RLS, the number of patients diagnosed and treated in the community is low. It is known that the disease is associated with serum ferritin levels and the peripheral and central nervous systems. Sensory symptoms are especially important in the disease. In this study, no relationship was found between ferritin serum levels and sensory nerve conduction. It was determined that the disease was particularly associated with slow sural sensory nerve conduction velocity. There is a need for new studies evaluating more patients and other sensory nerves.

Ethics

Ethics Committee Approval: Selcuk University Hospital Clinical Research Ethics Committee (meeting number: 2019/15, decision number: 2019/339).

Informed Consent: No patients were investigated without informed consent, and their data were not included in the study.

Peer-review: Externally and internally peer-reviewed.

\section{Authorship Contributions}

Concept: F.E., Ş.Ö., Design: F.E., Ş.Ö., Data Collection or Processing: F.E., A.D., Analysis or Interpretation: Ş.Ö., F.E., Literature Search: F.E., A.D., Writing: F.E.

Conflict of Interest: No conflict of interest was declared by the authors. 
Financial Disclosure: The authors declared that this study received no financial support.

\section{References}

1. Allen RP, Picchietti D, Hening WA, et al. Restless legs syndrome: Diagnostic criteria, special considerations, and epidemiology. A report from the restless legs syndrome diagnosis and epidemiology workshop at the National Institutes of Health. Sleep Med 2003;4:101-119.

2. Winkelman JW, Gagnon A, Clair AG. Sensory symptoms in restless legs syndrome: the enigma of pain. Sleep Med 2013;14:934-942.

3. Berger K, Kurth T. RLS-Epidemiology-frequencies, risk factors and methods in population studies. Mov Disord 2007;22:420-423.

4. Paulus W, Dowling P, Rijsman R, et al. Pathophysiological concepts of restless legs syndrome. Mov Disord 2007;22:1451-1456.

5. Fulda S, Wetter TC. Emerging drugs for restless legs syndrome. Expert Opin Emerg Drugs 2005;10:537-552.

6. Gemignani F, Vitetta F. Sensory profile in primary restless legs syndrome and restless legs syndrome associated with small fibre neuropathy. Brain 2010;134:167-168.

7. Schattschneider J, Bode A, Wasner G, et al. Idiopathic restless legs syndrome: Abnormalities in central somatosensory processing. J Neurol 2004;251:977-982.

8. Gemignani F, Brindani F, Negrotti A, et al. Restless legs syndrome and polyneuropathy. Mov Disord 2006;21:1254-1257.

9. Rutkove SB, Matheson JK, Logigian EL. Restless legs syndrome in patients with polyneuropathy. Muscle Nerve 1996;19:670-672.

10. Nineb A, Rosso C, Dumurgier J, et al. Restless legs syndrome is frequently overlooked in patients being evaluated for polyneuropathies. Eur J Neurol 2007;14:788-792.

11. Bastia JK, Bhoi SK, Kalita J, Misra UK. Neuropathy in a cohort of restless leg syndrome patients. J Clin Neurosci 2015;22:1314-1318.

12. Hattan E, Chalk C, Postuma RB. Is there a higher risk of restless legs syndrome in peripheral neuropathy? Neurology 2009;72:955-960.

13. Cuellar NG, Dorn JM. Peripheral diabetic neuropathy or restless legs syndrome in persons with type 2 diabetes mellitus: differentiating diagnosis in practice. J Am Assoc Nurse Pract 2015;27:671-675.
14. Rajabally YA, Shah RS. Restless legs syndrome in chronic inflammatory demyelinating polyneuropathy. Muscle Nerve 2010;42:252-256.

15. Bollu PC, Yelam A, Thakkar MM. Sleep Medicine: Restless Legs Syndrome. Mo med 2018;115:380-387.

16. Allen RP, Picchietti DL, Garcia-Borreguero D, et al. Restless legs syndrome/ Willis-Ekbom disease diagnostic criteria: updated International Restless Legs Syndrome Study Group (IRLSSG) consensus criteria--history, rationale, description, and significance. Sleep Med 2014;15:860-873.

17. Cho YW, Kang MS, Kim KT, et al. Quantitative sensory test for primary restless legs syndrome/Willis-Ekbom disease using the current perception threshold test. Sleep Med 2017;30:19-23.

18. Gemignani F, Brindani F, Vitetta F, Marbini A. Restless legs syndrome and painful neuropathy-retrospective study. A role for nociceptive deafferentation? Pain Med 2009;10:1481-1486

19. Gemignani F, Brindani F, Vitetta F, Marbini A, Calzetti S. Restless legs syndrome in diabetic neuropathy: a frequent manifestation of small fiber neuropathy. J Peripher Nerv Syst 2007;12:50-53.

20. Akın S, Bölük C, Börü ÜT, et al. Restless legs syndrome in type 2 diabetes mellitus. Prim Care Diabetes 2019;13:87-91.

21. Domínguez RO, Michref A, Tanus E, Amartino H. Restless legs syndrome in Fabry disease: clinical feature associated to neuropathic pain is overlooked. Rev Neurol 2007;45:474-478.

22. Gemignani F, Vitetta F, Brindani F, Contini M, Negrotti A. Painful polyneuropathy associated with restless legs syndrome. Clinical features and sensory profile. Sleep Med 2013;14:79-84.

23. Killian JM, Foreman PJ. Clinical utility of dorsal sural nerve conduction studies. Muscle Nerve 2001;24:817-820.

24. Im S, Kim SR, Park JH, Kim YS, Park GY. Assessment of the medial dorsal cutaneous, dorsal sural, and medial plantar nerves in impaired glucose tolerance and diabetic patients with normal sural and superficial peroneal nerve responses. Diabetes Care 2012;35:834-839.

25. Trenkwalder C, Paulus W, Walters AS. Restless Legs syndrome. Lancet Neurol 2005; 4:465-475

26. Kim KW, Yoon IY, Chung S, et al. Prevalence, comorbidities and risk factors of restless legs syndrome in the Korean elderly population-results from the Korean Longitudinal Study on Health and Aging. J Sleep Res 2010;19:8792 